University of Nebraska - Lincoln

DigitalCommons@University of Nebraska - Lincoln

Publications, Agencies and Staff of the U.S.

Department of Commerce

U.S. Department of Commerce

2011

\title{
Evidence of susceptibility to morbillivirus infection in cetaceans from the United States
}

T. K. Rowles

National Marine Fisheries Service

L. S. Schwacke

NOAA's Ocean Service

R. S. Wells

Mote Marine Laboratory

J. T. Saliki

University of Georgia

L. Hansen

National Marine Fisheries Service

See next page for additional authors

Follow this and additional works at: https://digitalcommons.unl.edu/usdeptcommercepub

Part of the Environmental Sciences Commons

Rowles, T. K.; Schwacke, L. S.; Wells, R. S.; Saliki, J. T.; Hansen, L.; Hohn, A.; Townsend, F.; Sayre, R. A.; and Hall, A. J., "Evidence of susceptibility to morbillivirus infection in cetaceans from the United States"

(2011). Publications, Agencies and Staff of the U.S. Department of Commerce. 313.

https://digitalcommons.unl.edu/usdeptcommercepub/313

This Article is brought to you for free and open access by the U.S. Department of Commerce at DigitalCommons@University of Nebraska - Lincoln. It has been accepted for inclusion in Publications, Agencies and Staff of the U.S. Department of Commerce by an authorized administrator of DigitalCommons@University of Nebraska - Lincoln. 


\section{Authors}

T. K. Rowles, L. S. Schwacke, R. S. Wells, J. T. Saliki, L. Hansen, A. Hohn, F. Townsend, R. A. Sayre, and A. J. Hall 
MARINE MAMMAL SCIENCE, 27(1): 1-19 (January 2011)

2010 by the Society for Marine Mammalogy

Published 2010. This article is a US Government work and is in the public domain in the USA.

DOI: $10.1111 / \mathrm{j} .1748-7692.2010 .00393 . x$

\title{
Evidence of susceptibility to morbillivirus infection in cetaceans from the United States
}

\author{
T. K. ROWLES
}

National Marine Fisheries Service,

Marine Mammal Health and Stranding Response Program,

1315 East-West Highway,

Silver Spring, Maryland 20910, U.S.A.

L. S. SCHWACKE

NOAA's Ocean Service,

Center for Human Health Risks,

331 Fort Johnson Road,

Charleston, South Carolina 29412, U.S.A.

\section{R. S. WELLS}

Chicago Zoological Society,

\% Mote Marine Laboratory,

1600 Ken Thompson Parkway,

Sarasota, Florida 34236, U.S.A.

\section{J. T. SALIKI}

Athens Veterinary Diagnostic Laboratory,

University of Georgia,

Athens, Georgia 30602, U.S.A.

\section{HANSEN}

A. $\mathrm{HOHN}$

National Marine Fisheries Service,

Southeast Fisheries Science,

NOAA Beaufort Laboratory,

101 Pivers Island Road,

Beaufort, North Carolina 28516, U.S.A.

\section{F. TOWNSEND}

Bayside Hospital for Animals,

251 N.E. Racetrack Road,

Fort Walton Beach, Florida 32547, USA

\section{R. A. SAYre}

NOAA's Ocean Service,

Center for Human Health Risks,

331 Fort Johnson Road,

Charleston, South Carolina 29412, U.S.A. 


\author{
A. J. HALL ${ }^{1}$ \\ Sea Mammal Research Unit, \\ Scottish Oceans Institute, \\ University of St Andrews, \\ Fife, KY16 8LB, United Kingdom \\ E-mail:ajh7@st-andrews.ac.uk
}

\begin{abstract}
Cetacean morbilliviruses (CeMV) are viruses that can cause mass mortalities among various odontocete species. In this study levels of "herd" immunity in cetaceans from the U.S. coast are described from the distribution and prevalence of antibodies against morbilliviruses. Neutralizing antibody titers against dolphin morbillivirus (DMV), porpoise morbillivirus (PMV), phocine distemper (PDV), and canine distemper viruses (CDV) were measured. Positive samples had higher titers against the CeMV than against the other morbilliviruses tested, indicating that although PDV or CDV can be used to investigate exposure their use may result in a higher false negative rate. The results suggest that morbillivirus did not persist in coastal populations of bottlenose dolphins (Tursiops truncatus) after the major outbreaks that occurred in the 1980s and 1990s. Bottlenose dolphins from Beaufort, North Carolina; St. Joseph Bay, Florida; and Cape May, New Jersey had anti-DMV seroprevalences ranging from between $15 \%$ and $33 \%$ but those from Charleston, South Carolina and Sarasota Bay, Florida, sampled in recent years were largely negative. These latter groups are therefore now vulnerable to infection and could experience high mortality if exposed to CeMV. Sero-surveys of this kind are therefore vital for assessing the risk of new and recurring viral outbreaks in coastal cetaceans.
\end{abstract}

Key words: infectious disease, bottlenose dolphin, Tursiops truncatus, serology, Atlantic Ocean.

The emergence and history of morbillivirus infection in cetacean populations worldwide has been well documented (Domingo et al. 1990; Van Bressem et al. 1991, 1998, 2001; Welsh et al. 1992; Aguilar and Raga 1993; Barrett et al. 1993; Lipscomb et al. 1994a, b; Barrett et al. 1995; Duignan et al. 1995a, 1996; Hall 1995; Saliki et al. 2002). Two antigenically and genetically very similar cetacean morbillivirus strains have been described, namely dolphin morbillivirus (DMV, first isolated in striped dolphins (Stenella coeruleoalba) from the Mediterranean sea in 1990) and porpoise morbillivirus (PMV, first isolated in harbor porpoises (Phocoena phocoena) from the NE Atlantic in 1988) (Kennedy et al. 1988, McCullough et al. 1991, Visser et al. 1993). These viruses, together with phocine distemper virus (PDV) and canine distemper virus (CDV), have impacted various marine mammal populations worldwide since they were first identified in the late 1980s (Hall 1995, Kennedy 1998). These relatively recent additions to the Paramyxoviridae family have affected a variety of small odontocete cetaceans in Europe and North America. A major outbreak of the disease occurred in 1987-1988 among common bottlenose dolphins (Tursiops truncatus) in the United States, which spanned stocks from New Jersey to Florida

\footnotetext{
${ }^{1}$ Author to whom correspondence should be addressed.
} 
(Geraci 1989, Lipscomb et al. 1994b). In addition, analysis of tissues from dolphins that stranded in the Gulf of Mexico in 1992-1993 during an unusual mortality event also found morbilliviral RNA (Lipscomb et al. 1994a, b). Further sequence analyses of the isolates from these outbreaks found DMV to be more prevalent in the north Atlantic whereas PMV was more common farther south (Taubenberger et al. 1996). Indeed, only PMV was detected in samples from dolphins that died during the 1993 Gulf of Mexico epidemic whereas both viruses were found in victims of the 19871988 outbreak. However, the first documented dolphin morbillivirus epidemic in the United States may have occurred as early as 1982 in the Indian/Banana River Lagoon of Florida. Duignan et al. (1996) concluded retrospectively that the marked increase in strandings in the region and the presence of seropositive individuals in a previously naïve population was indicative of an outbreak which did not persist.

However, probably the largest outbreak of morbillivirus among cetaceans occurred between 1990 and 1992 among striped dolphins in the Mediterranean Sea (Domingo et al. 1990). Thousands of animals died during this outbreak and subsequent genetic studies of the isolated virus indicated that it was distinctly different from PDV (Barrett et al. 1993), which had emerged in the European harbor seal (Phoca vitulina) in 1988 (Osterhaus and Vedder 1988). It was subsequently named dolphin morbillivirus (Visser et al. 1993). In 1994 common dolphins (Delphinus delphis) in the Black Sea were also affected by a morbillivirus (Birkun et al. 1999). In the summer of 2007 there was then a second outbreak of dolphin morbillivirus among the Mediterranean striped dolphins (Raga et al. 2008) when $>100$ animals stranded due to infection. Other species affected include the long-finned pilot whale (Globicephala melas) that stranded along the southern Spanish Mediterranean coast in 2006-2007 (Fernandez et al. 2008).

In addition, during the PDV outbreak among seals, a morbillivirus was isolated from two harbor porpoises on the coast of Northern Ireland. At necropsy these animals displayed all the pathological signs consistent with morbillivirus infection including severe pneumonia, syncytia formation, and necrosis of the bronchial and bronchiolar epithelium. Acidophilic intracytoplasmic inclusion bodies were seen in the bronchial and bronchiolar epithelium that is highly specific for morbillivirus infection (Kennedy et al. 1988). Subsequently a morbillivirus was isolated from two harbor porpoises that died in the Dutch Wadden Sea (Visser et al. 1993), distinctly different from DMV when tested against a panel of monoclonal antibodies and in cell culture. This virus was therefore named porpoise morbillivirus.

These outbreaks prompted a number of serological surveys to determine previous morbillivirus exposure, particularly among the odontocete cetaceans, which appear to be especially vulnerable to infection (Visser et al. 1993; Duignan et al. 1995a, 1996; Van Bressem et al. 1998, 2001; Nielsen et al. 2000). Serological surveys remain the predominant method for determining exposure to disease as well as identifying current immune status, particularly for marine mammals and other wildlife, where samples for viral antigen studies are difficult to obtain (Haydon et al. 2002, Thompson et al. 2002). The prevalence of pathogen-specific antibodies (i.e., the proportion of seropositive animals with antibody titers above an established threshold) is determined from serum samples. In the case of viruses inducing a long-lasting immunity, such as morbilliviruses, past exposure can be determined using serology. Disease endemicity has been inferred for morbilliviruses in marine mammal populations from studies where very high sero-prevalence proportions were found (Dietz et al. 1989; Markussen and Have 1992; Duignan et al. 1995a, b; Van Bressem et al. 1998, 2001) but this can only be definitively concluded when it can 
be demonstrated that both young and older age-classes have antibodies. However, the distribution of antibody titers can be of value even without age-specific details. Because antibody levels generally increase shortly after exposure to an infection and then decline over time (Lloyd-Smith et al. 2007), the titer values can provide information on time since exposure or infection. Therefore, if a pathogen was present but it has not persisted in a population a few individuals might have high titers but most are likely to have lower titers (Cornwell et al. 1992), whereas if the pathogen is still present, the mean titers within the population are likely to be higher, as was seen during the PDV outbreaks in Europe in 1988 and 2002 (Pomeroy et al. 2005).

Here we investigate the distribution and prevalence of virus neutralizing antibodies to morbilliviruses in cetaceans from around the United States. We used two sources of serum samples, (1) sera collected during live capture-release programs for bottlenose dolphins and (2) additional sera obtained from freshly stranded cetaceans (various species) sampled as part of the U.S. Marine Mammal Health and Stranding Response Program. By comparing titers to different morbilliviruses, the primary antigen to which the dolphins were exposed can be inferred.

\section{Methods}

Bottlenose dolphins were sampled from five locations along the U.S. Atlantic and Gulf of Mexico coasts during capture-release operations between 1989 and 2006. In the stranded animals, a variety of different cetacean species were sampled between 1999 and 2004. Neutralizing antibody titers against the two cetacean viruses, DMV and PMV, were measured, together with titers against the pinniped morbillivirus, PDV and the terrestrial carnivore morbillivirus, CDV.

\section{Live Capture-Release}

Serum samples were collected during live capture release, health assessment studies being carried out in U.S. coastal waters (Schwacke et al. 2004). Figure 1 shows the five locations sampled: Beaufort, North Carolina; Cape May, New Jersey; Charleston, South Carolina; Sarasota Bay, Florida; and St. Joseph Bay, Florida. The capture and release techniques are fully described in Wells et al. $(2004,2005)$ and are summarized here. Small groups of dolphins were encircled using a seine net and each individual was placed in a stretcher and lifted onto a veterinary examination vessel, where it was weighed and measured. Blood samples were drawn from a vessel in the fluke into serum separator tubes (Becton Dickinson, Franklin Lakes, NJ, USA). The serum was removed after centrifugation and stored at $-20^{\circ} \mathrm{C}$ or below for serology and other clinical studies. A tooth was removed for age determination only when an animal's age was unknown (Hohn et al. 1989).

The number of serum samples collected by location and year (1999-2006) is shown in Table 1 . This ranged from between 12 and 14 serum samples obtained from Cape May and Charleston, up to 70 samples obtained from the more frequent sampling effort for the Sarasota Bay population. In addition 27 serum samples (from 8 females and 5 males) from Sarasota Bay dolphins captured, released and subsequently recaptured and resampled between 1989 and 2001 were screened for the presence of anti-DMV antibodies. To avoid duplication of the results the recaptured animals were excluded from the first group. This was the case for only one animal (FB63, Table 5) which was captured and released four times between 1989 and 2001. 


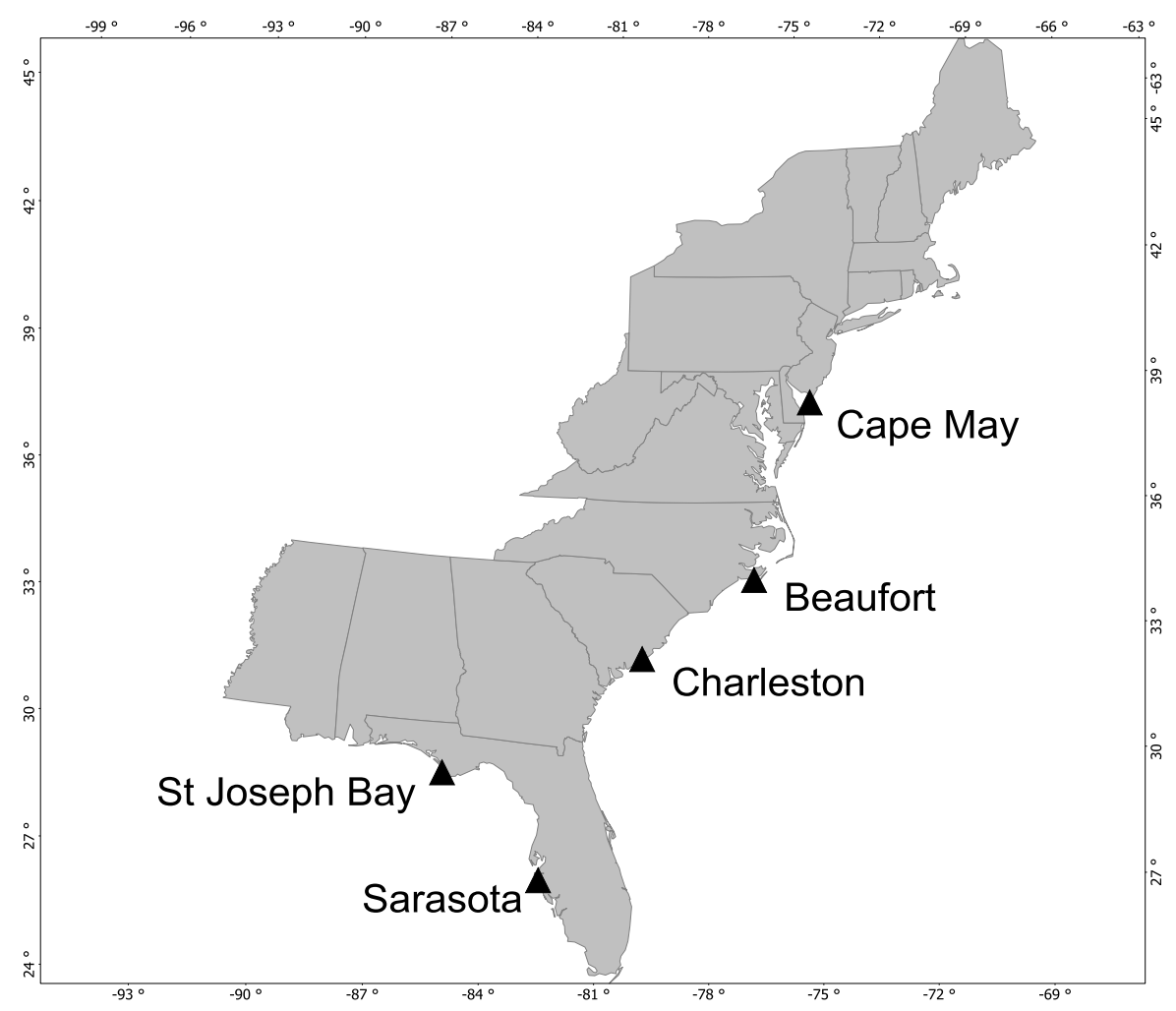

Figure 1. Locations of the bottlenose dolphin cross-sectional live capture study sites.

\section{Stranded Cetaceans}

Blood samples collected from animals that stranded live (stranding condition code 1) were obtained from the tail fluke using the same method as for the live captured animals. Those obtained from freshly dead or euthanized individuals were collected from the aorta into a plain Vacutainer tube. Samples were centrifuged and the serum stored at $-20^{\circ} \mathrm{C}$ until testing. The number of animals sampled by species and year is shown in Table 2. Most samples were collected from single stranded animals except for two groups of cetaceans that mass-stranded during the study

Table 1. Number of bottlenose dolphin serum samples tested by year.

\begin{tabular}{|c|c|c|c|c|c|c|c|c|c|}
\hline Location & 1999 & 2000 & 2001 & 2002 & 2003 & 2004 & 2005 & 2006 & Total \\
\hline Beaufort & 2 & 11 & & & & & & 18 & 31 \\
\hline Cape May & & & & 7 & 5 & & & & 12 \\
\hline Charleston & 14 & & & & & & & & 14 \\
\hline Sarasota Bay & & & 5 & 8 & 16 & 33 & 8 & & 70 \\
\hline St. Joseph Bay & & & & & & & 9 & 18 & 27 \\
\hline Total & 16 & 11 & 5 & 15 & 21 & 33 & 17 & 36 & 154 \\
\hline
\end{tabular}


Table 2. Number of stranded cetaceans tested by year.

\begin{tabular}{|c|c|c|c|c|c|c|}
\hline \multirow[b]{2}{*}{ Common name } & \multicolumn{5}{|c|}{ Year } & \multirow[b]{2}{*}{ Total } \\
\hline & 1999 & 2001 & 2002 & 2003 & 2004 & \\
\hline Atlantic white-sided dolphin & & & & 1 & & 1 \\
\hline Bottlenose dolphin & & 1 & 1 & 3 & 4 & 9 \\
\hline Clymene dolphin & & & & & 2 & 2 \\
\hline Common dolphin (short-beaked) & & & & 1 & 3 & 4 \\
\hline Fin whale & & & & & 1 & 1 \\
\hline Fraser's dolphin & & & & 10 & & 10 \\
\hline Harbor porpoise & 1 & & & & 5 & 6 \\
\hline Humpback whale & & & 1 & & & 1 \\
\hline Killer whale & & & 1 & & & 1 \\
\hline Long-finned pilot whale & & & & 1 & & 1 \\
\hline Melon headed whale & & & & & 1 & 1 \\
\hline Pantropical spotted dolphin & & & & & 1 & 1 \\
\hline Pygmy sperm whale & & & & & 2 & 2 \\
\hline Risso's dolphin & & & & 1 & 3 & 4 \\
\hline Rough-toothed dolphin & & & & & 8 & 8 \\
\hline Sei whale & & & 1 & & & 1 \\
\hline Spinner dolphin & & & & 1 & 1 & 2 \\
\hline Unspecified dolphin & & & & & 1 & 1 \\
\hline Total & 1 & 1 & 4 & 18 & 32 & 56 \\
\hline
\end{tabular}

period. These comprised 10 Fraser's dolphins (Lagenodelphis hosei) that stranded alive in Charlotte Harbor, Florida, in April 2003 and 7 rough-toothed dolphins (Steno bredanensis) that stranded alive on Hutchinson Island, St. Lucie, Florida, in August 2004 (an additional rough-toothed dolphin was also sampled in 2004).

\section{Serological Testing}

Antibody titers against four morbilliviruses were measured using the microtiter virus neutralization test (Rossiter et al. 1985) as described in Saliki and Lehenbauer (2001). The Rockborn strain of CDV, PDV strain 1-2-6A and the Belfast strains of DMV and PMV (kindly donated by Dr. S. Kennedy, Department of Agriculture and Rural Development, Belfast, Northern Ireland) were used in the assays. Viruses were grown in African green monkey kidney (Cercopithecus aethiops, Vero) cells (a common cell line for morbillivirus isolation and propagation) using the alpha modification of Eagle's minimum essential medium supplemented with Earle's salts, L-glutamine, $10 \%$ fetal bovine serum (FBS), and antibiotics (100 $\mathrm{U}$ of penicillin and $100 \mu \mathrm{g}$ of streptomycin per $\mathrm{mL})$. Twofold dilutions of sera $(25 \mu \mathrm{L})$ were made in triplicate in 96-well microtiter plates with minimum essential medium with Earle's salts (EMEM) containing 5\% fetal bovine serum. An equal volume of virus $(25 \mu \mathrm{L})$ containing approximately $100 \mathrm{TCID}_{50}$ was added to two wells of each triplicate with the third well containing EMEM as a control. Plates were incubated at $37^{\circ} \mathrm{C}$ for $1 \mathrm{~h}$. Vero cells $\left(1.5 \times 10^{4}\right.$ cells in $\left.150 \mu \mathrm{L}\right)$ were added and the plates incubated at $37^{\circ} \mathrm{C}$ in $5 \% \mathrm{CO}_{2}$. The plates were read after $4 \mathrm{~d}$ by examining cell monolayers for virus-specific cytopathic effects (CPE). Titers were expressed as the reciprocal of the 
highest dilution of serum that completely neutralized CPE in both duplicate wells. Titers were also $\log _{2}$ transformed to linearize the scale.

\section{RESULTS}

\section{Cross Sectional Live Capture Samples}

The sera of 137 bottlenose dolphins were titrated against DMV. The sera of 114 of these were also tested for the presence of antibodies against PMV, PDV, and CDV. The relationship among the titers ( $\log _{2}$ transformed) is shown in Figure $2 \mathrm{~A}, \mathrm{~B}$. The DMV titers were generally higher than for the other morbilliviruses, especially when compared to the CDV and PDV titers (Fig. 2B shows that among the seropositive titers all were higher against DMV than CDV, above the line of equivalence shown). This indicates the animals were most likely to have been exposed to DMV, since the titers against the homologous virus will always be the highest (Visser et al. 1990, Duignan et al. 1994). If the other morbillivirus antigens (PDV or CDV) had been used as a surrogate this would have produced a very high proportion of false negative results $(11 \%)$.

Table 3 shows the frequency of serum DMV titers by location, combining all years (1999-2006) as there was insufficient data to consider temporal as well as spatial trends. Titers $\geq 1: 16\left(\log _{2}=4\right)$ were taken as seropositive. The distribution of titers against PMV in the Beaufort and St. Joseph Bay animals are also shown. In the animals from Beaufort sampled in 2006, the two seropositive individuals had higher titers against PMV than against DMV and all the seropositive animals sampled in St. Joseph Bay in $2006(n=4)$ had titers that were higher against PMV. Overall, in Beaufort in 2006 and St. Joseph Bay in both 2005 and 2006, 16\% (7/45) of the sampled individuals had seropositive titers that were higher against PMV than DMV which may indicate that the virus now circulating along the east coast of the United States and into the Gulf of Mexico is more likely to be the PMV strain than the DMV strain. However, all the PMV seropositive animals were also seropositive against DMV. Thus, in the further analyses of the prevalence of morbillivirus antibodies, the DMV titers will be used for all sites, since even though the PMV titers were higher in some animals from these two regions, the prevalence proportions do not change.

Table 3 also shows the prevalence (\%) of seropositive animals at each location and the $95 \%$ confidence intervals around these prevalences. The confidence intervals indicate the likely range and therefore the reliability of the prevalence estimates, given the sample sizes in each group. A Fisher's exact test (two-sided) for differences among proportions found the prevalences to be significantly different among the locations $(P<0.0001)$. Charleston and Sarasota Bay had no seropositive samples, in contrast to the longitudinal samples from Sarasota Bay (see section further). Beaufort and Cape May had similar seropositive proportions of about 20\%-30\%. These two sites also included the animals with the highest titers $(\geq 1: 256)$. The prevalence of seropositive dolphins from St. Joseph Bay was $18 \%$ (Table 3).

We found that increasing the seropositive threshold from $\geq 1: 16$ to $\geq 1: 32$ did not significantly affect the results. The prevalences in samples from Beaufort and Cape May at $\geq 1: 32$ reduced to $13 \%$ and $25 \%$, respectively. This did not substantially affect any conclusions regarding exposure and susceptibility, thus we retained a seropositive threshold of $\geq 1: 16$. 


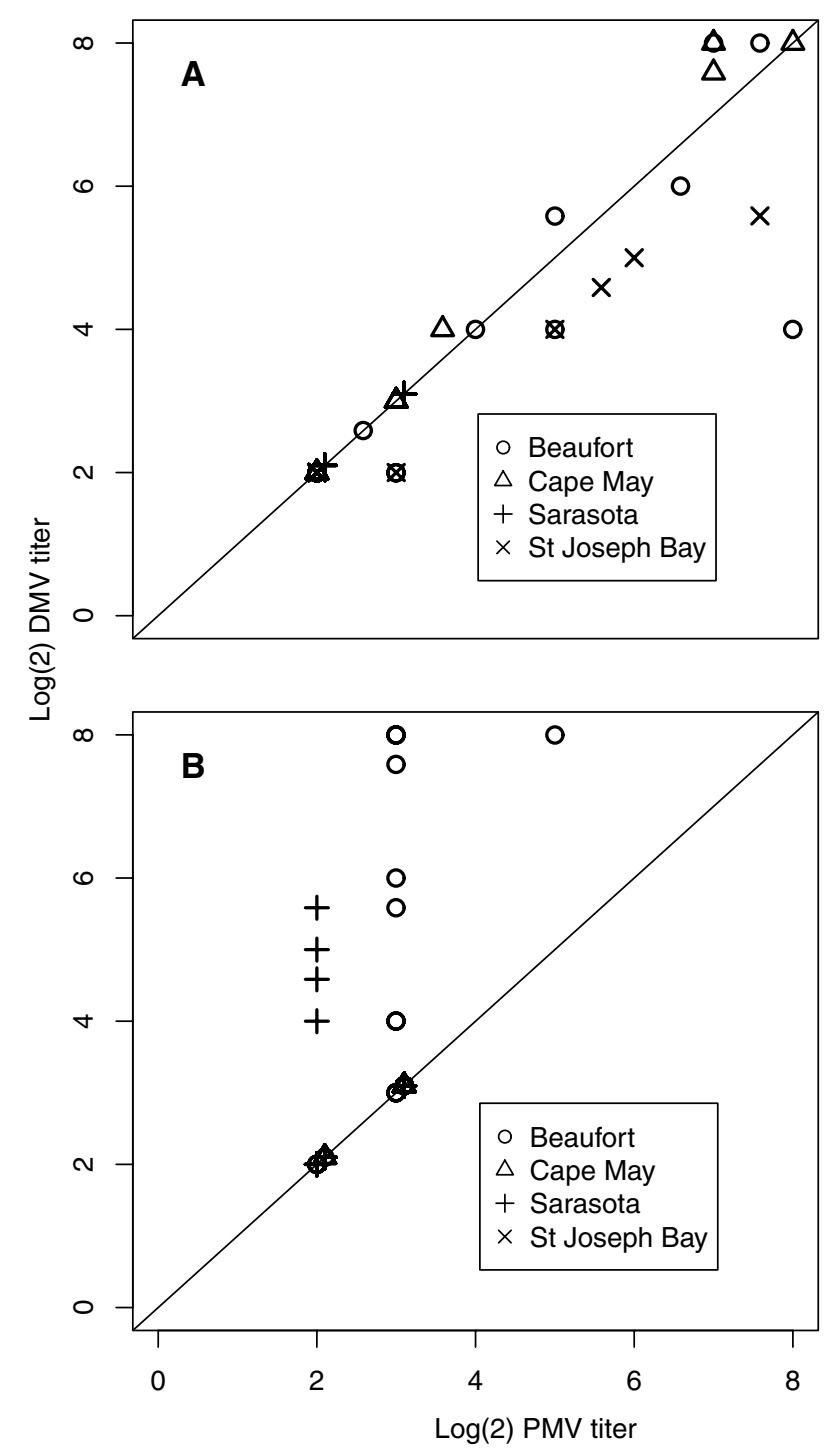

Figure 2. Comparison of $\log _{2}(\mathrm{DMV})$ against (A) $\log _{2}(\mathrm{PMV})$ titers and $(\mathrm{B}) \log _{2}(\mathrm{CDV})$ titers.

The percent positive (prevalence) and the number of seronegative or seropositive by region and year of birth (where this was available, $n=125$ ) are shown inTable 4 . The majority of seropositive samples $\left(\geq 1: 16, \log _{2} \geq 4\right)$ were from individuals born prior to a documented morbillivirus outbreak within their region of capture. For samples from the eastern U.S. Atlantic coast (Cape May, Beaufort, and Charleston), only one seropositive individual was born subsequent to the 1987-1988 morbillivirus outbreak. This individual's titer was relatively low (1:16) and his estimated year of birth was 1989 (11 yr old at time of capture), suggesting that the virus circulated 


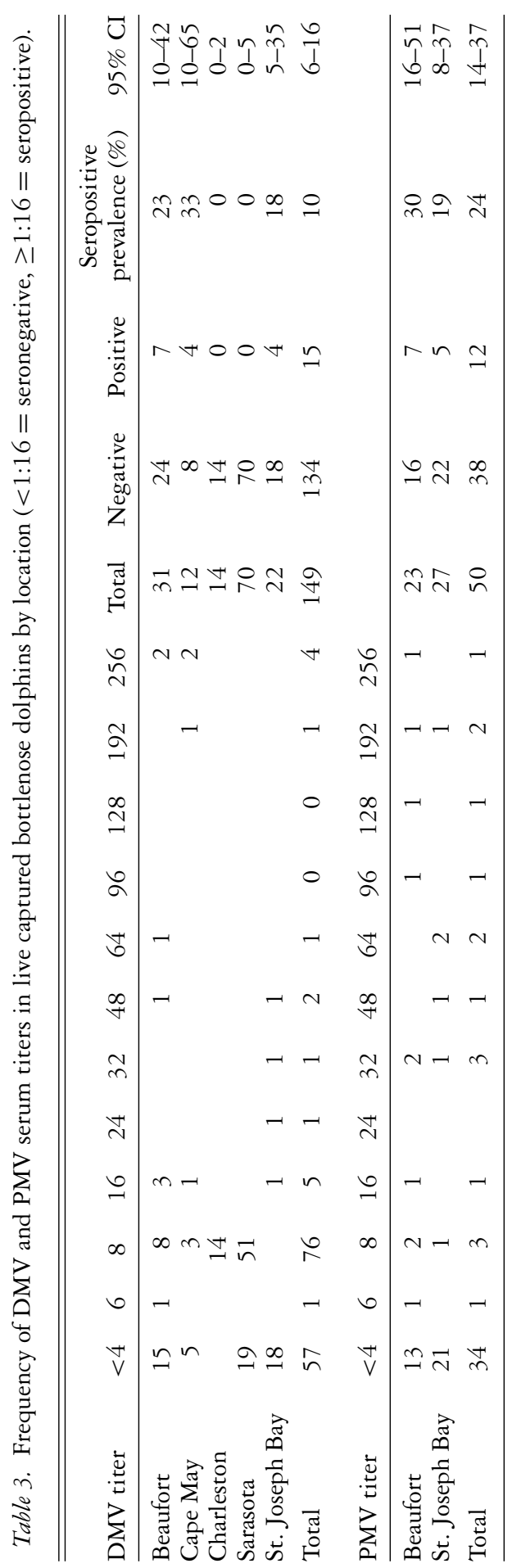




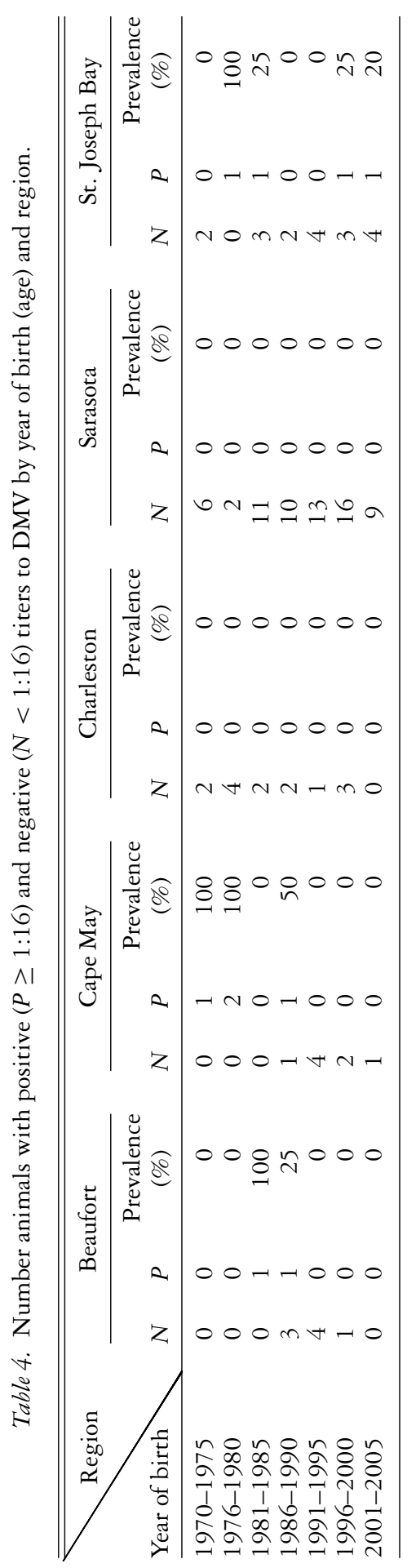


for some months past the end of the observed die-off. Similarly, two relatively young ( $\sim 2 \mathrm{yr}$ and $8 \mathrm{yr}$ old $)$ dolphins sampled from St. Joseph Bay with estimated birth years subsequent to the 1992-1993 Gulf of Mexico morbillivirus outbreak also had low titers (1:16 and 1:32). There is a small possibility that the observed titer, at least in the younger animal, was remnant maternal antibody. There was no difference in the distribution of titers between the sexes (Mann Whitney $U$-test, $P=0.596$ ).

\section{Longitudinal Samples from Sarasota Bay}

The results from serum samples collected longitudinally from the Sarasota Bay dolphins between 1989 and 2001 are shown in Table 5. Between 1989 and 1994 almost half of the animals sampled $(6 / 13,46 \%)$ had a high DMV titer $\geq 1: 64$ up to a maximum of 1:256 (Table 5). The four individuals that were followed until 2000-2001 showed a subsequent decline or essentially no change in titers between around 1993 and 2001 (a fourfold change in titer is generally considered clinically significant, Bonilla et al. 2005). Interestingly, one animal (FB63), captured four times over an 11-yr period had a consistently relatively high titer ranging from 1:64 to $1: 192$, These results are in contrast to the recent results reported above, in which none of the additionally captured Sarasota Bay dolphins between 1999 and 2006 had seropositive morbillivirus titers.

\section{Stranded Cetaceans}

The stranded cetacean samples were obtained from live and freshly dead animals and they comprised two categories, single stranded animals and groups. The geographical locations of single stranded animals that provided samples are plotted in Figure 3. The most common species were bottlenose dolphins $(n=9)$ and harbor porpoises $(n=6$, Table 2$)$. Thirty-three animals were seronegative and six were seropositive. Since genetic studies were not carried out on the bottlenose dolphins, it is not possible to determine whether they were coastal or offshore animals. The titers against the four morbilliviruses for the seropositive animals are listed in Table 6. In four species titers were higher against DMV than the other morbilliviruses, but in two bottlenose dolphins, titers were again higher against PMV than DMV. One rough-toothed dolphin stranded in the Gulf of Mexico had a very high titer against DMV but all serum samples from the two mass-strandings (Fraser's dolphins and rough-toothed dolphins, $n=17$ ) were negative.

\section{DisCUSSION}

This study describes the distribution of neutralizing antibody titers against various morbilliviruses in cetaceans from U.S. waters. Three different sample sources were used; serum collected during live capture-release studies, from live-stranded animals, and from freshly dead animals. Here we used a titer threshold of $\geq 1: 16$ to classify animals as having positive, protective antibody levels. Other studies of neutralizing antibodies to morbilliviruses in marine mammals have used different seropositive thresholds, ranging between $\geq 1: 16$ and $\geq 1: 64$ (Duignan et al. 1996, Thompson et al. 1992, Nielsen et al. 2000, Thompson et al. 2002). Because of this variation, we investigated the effect of changing the threshold. We found that increasing the cut-off from $\geq 1: 16$ to $\geq 1: 32$ did not substantially change the prevalence results 


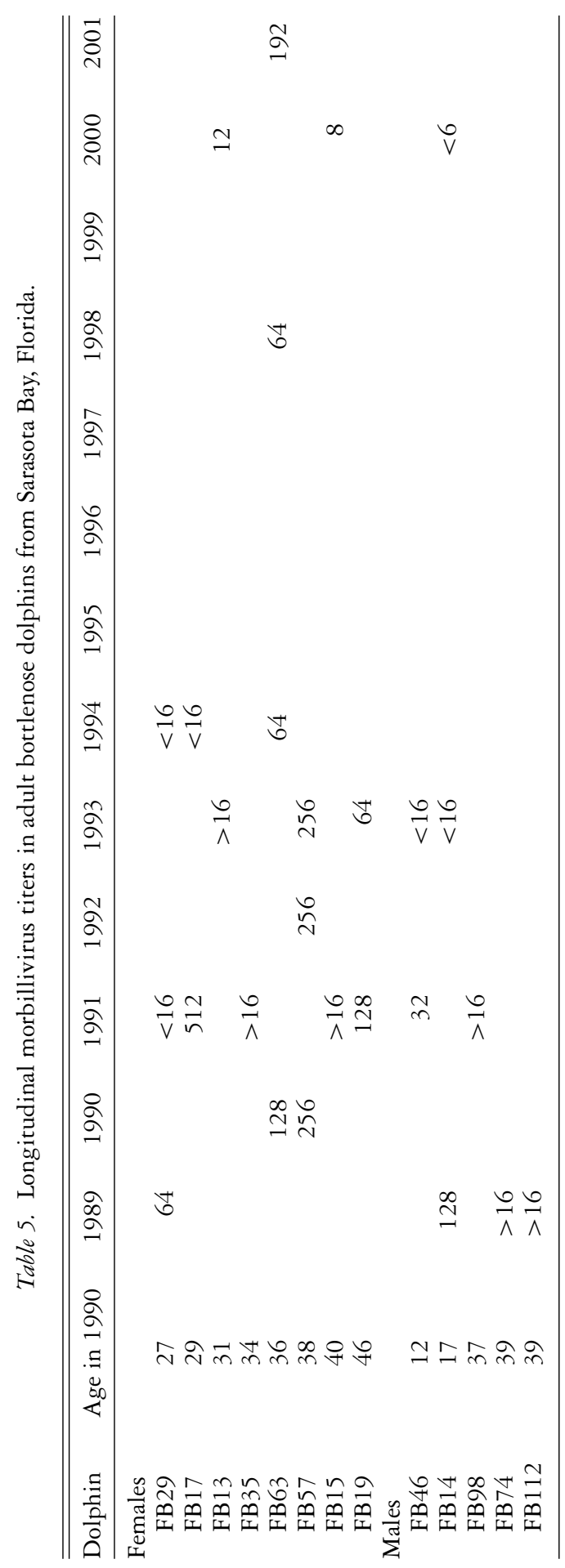




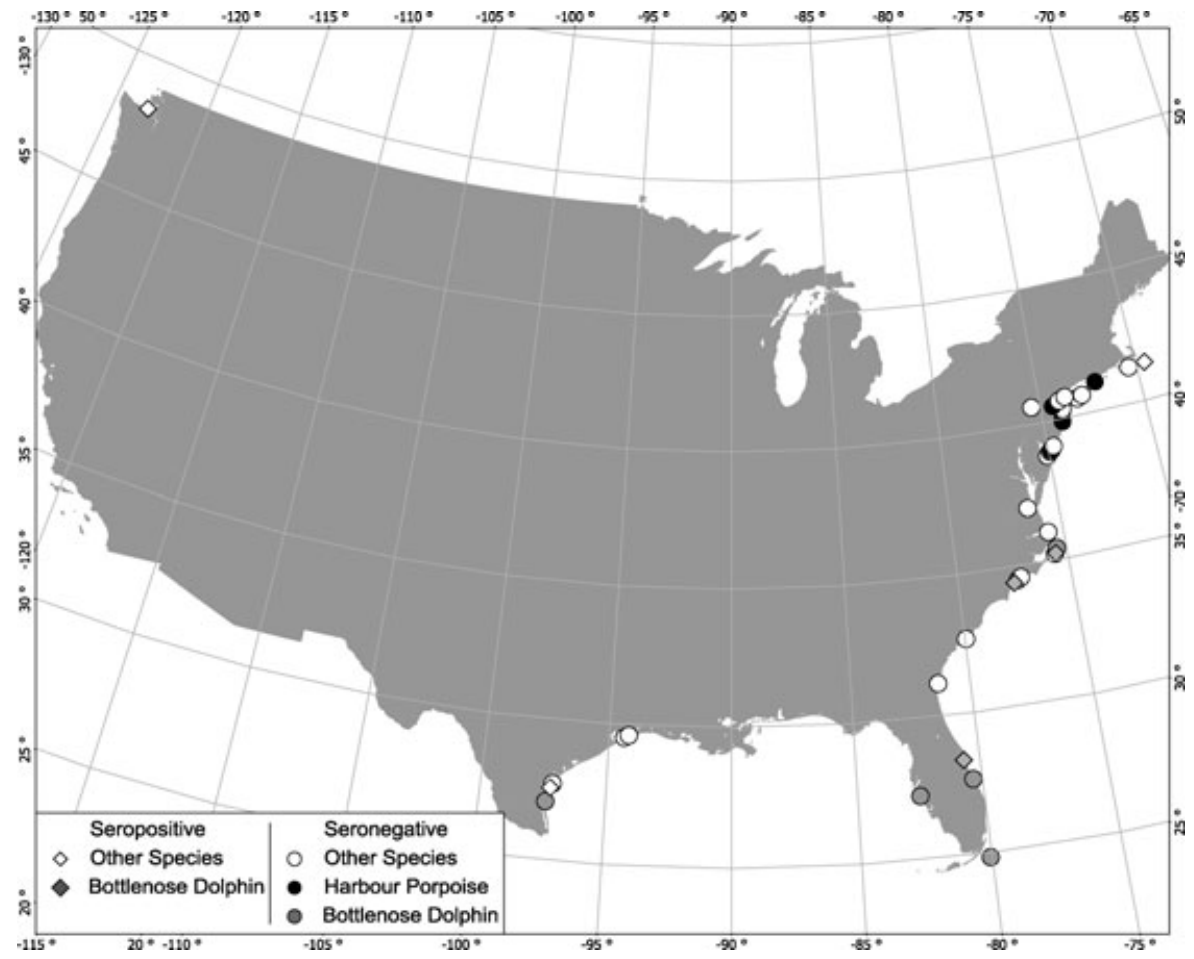

Figure 3. Geographical locations of single stranded cetaceans tested for morbillivirus antibodies.

or conclusions from the study, indicating the robustness of using $\geq 1: 16$ as the seropositive threshold titer. While other studies might continue to use a higher threshold (Thompson et al. 2002), a slightly more cautionary approach is warranted in studies of vulnerable species, particularly when they are not sampled during an epidemic. However, a higher threshold is also recommended when using hemolyzed sera that may be toxic to the virus.

Table 6. Differential morbillivirus neutralization titers in single stranded cetaceans.

\begin{tabular}{lcllrrrr}
\hline \hline $\begin{array}{l}\text { Latitude } \\
\left({ }^{\circ} \mathrm{N}\right)\end{array}$ & $\begin{array}{c}\text { Longitude } \\
\left({ }^{\circ} \mathrm{W}\right)\end{array}$ & \multicolumn{1}{c}{ Date } & \multicolumn{1}{c}{ Species } & DMV & PMV & CDV & PDV \\
\hline 28.35139 & 80.65060 & 12 July 2001 & Bottlenose dolphin & 16 & 16 & 4 & 8 \\
48.17629 & 123.13700 & 2 January 2002 & Killer whale & 64 & 32 & 16 & 64 \\
41.37820 & 69.57470 & 18 October 2002 & Humpback whale & 32 & 32 & $<8$ & $<8$ \\
34.43000 & 77.54330 & 30 July 2004 & Bottlenose dolphin & 16 & 32 & $<8$ & $<8$ \\
35.25469 & 75.52030 & 6 August 2004 & Bottlenose dolphin & 64 & 128 & 4 & $<4$ \\
27.56667 & 97.21670 & 26 August 2004 & $\begin{array}{l}\text { Rough-toothed } \\
\text { dolphin }\end{array}$ & $\geq 256$ & 192 & $<4$ & $<4$ \\
& & & & & \\
\hline
\end{tabular}


The largest sample size for this serological survey was provided by the capturerelease studies of bottlenose dolphins that have been carried out on the east coast of the United States and in the Gulf of Mexico since 1989 (although in some locations the time series of samplings through capture-release has been much longer (Wells and Scott 1990)). The results suggest that, although morbilliviruses did not persist in coastal stocks after the 1980s outbreaks, PMV in particular may still be circulating in the southerly regions. This is in line with the findings of Taubenberger $e t$ al. (1996) who only found PMV and not DMV in a sample of the bottlenose dolphins that died during the Gulf of Mexico epidemic in 1993. In the study presented here, animals sampled in St. Joseph Bay had higher titers against PMV than against DMV. Although PMV was first isolated in a harbor porpoise (Kennedy et al. 1988), its natural host range has not been fully established. By contrast, in the Atlantic regions both viruses may be circulating, with DMV being more prevalent in the north, as was also reported in the late 1980s (Taubenberger et al. 1996). Clearly isolation and characterization of the viruses responsible for the serological test results would be advantageous.

Heterologous antigen has been widely used in neutralization assays to detect antibodies to emerging viruses from the same family, particularly for viruses that are difficult to isolate and culture (OIE 2008). While it is desirable to use homologous antigen, this is not always possible for both practical and economic reasons. However, as has been shown in this study, this compromise may produce biased results. A panel of four morbilliviruses was used to screen 114 bottlenose dolphin serum samples. When the correlation among the titers was examined (Fig. 2A, B) it indicated that the CeMV titers were largely greater than those for PDV or CDV. Thus, if CDV or PDV antigen alone had been used this would have resulted in a very high number of false negatives, illustrating the importance of using or developing a specific assay wherever possible.

In addition to the difference in the response to different morbillivirus antigens in the St. Joseph Bay population, two of the younger animals captured and sampled had seropositive titers, which could suggest recent exposure, since the animals would not have been present in the location at the time of the previous outbreaks. Future serological surveys in conjunction with viral RNA detection and phylogenetic analyses are needed to establish the likelihood of this conclusion $v$ s. the possibility that the observed titers were remnant maternal antibody. The lactation period for bottlenose dolphins is $\sim 2-3$ yr (Wells and Scott 1999), with the possibility of some continued passive immunity occurring throughout lactation (Corthésy-Theulaz et al. 2003). However, although calves as old as $7 \mathrm{yr}$ have been observed with lactating mothers in Sarasota Bay (Wells and Scott 1999) it seems unlikely that a juvenile as old as $8 \mathrm{yr}$ is continuing to receive maternal antibodies.

Serological surveys are, therefore, also important for establishing potential past exposure scenarios, particularly where age-prevalence data are available (Marschner 1996). It seems likely that bottlenose dolphins from estuaries in the Beaufort area were exposed in the past, possibly during the 1987-1988 morbillivirus outbreak. It had been thought that the estuary animals were not involved in this die-off (Geraci 1989) but either morbillivirus still is, and has been, circulating in the stock for over $15 \mathrm{yr}$ without establishing itself sufficiently to cause an epidemic (or indeed to become endemic), or that animals over $15 \mathrm{yr}$ of age were exposed in the $1980 \mathrm{~s}$ and have life-long immunity. Dolphins monitored with electronic tags in Beaufort during 1999 and 2000 were found to primarily inhabit the estuaries near Beaufort but many of them spent some time in nearshore waters (Hohn and Hansen, unpublished 
data). It is reasonable to assume that they would have come into contact with coastal migratory dolphins infected with morbillivirus during the 1987-1988 epizootic.

The most important conservation result from this study is that the bottlenose dolphins in Sarasota Bay, Florida, and in Charleston, South Carolina, which are relatively isolated, estuarine resident communities (Scott et al. 1990, Zolman 2002), have not been exposed to morbilliviruses in recent years, have essentially no protective antibody titers and are therefore highly vulnerable to infection if morbillivirus were to be reintroduced. Of some note is the finding that a morbillivirus was circulating in the long-term Sarasota Bay residents in the late 1980s and although one animal still had high antibody levels in 2001 animals sampled since then have been seronegative. ${ }^{2}$ In addition the animal with a high titer in 2001 (FB63) had been consistently highly seropositive since its first capture in 1990, perhaps indicating the individual variation in response and maintenance of titers, as is seen in human measles (Itoh et al. 2002). It appears that the virus did not persist perhaps because there was insufficient contact between infective and susceptible animals for the virus to spread or cause an epidemic and the disease then faded out. From the recent data we conclude that this population, spanning five generations, is now once again naïve. That dolphins inhabiting estuaries near Charleston were seronegative while those in Beaufort were seropositive might reflect differences between these locations in movements of dolphins from estuarine to coastal waters, with dolphins in Charleston being more insular. We know from the outbreak of DMV in striped dolphins in the Mediterranean (Aguilar and Raga 1993) and its re-emergence in 2007 (Raga et al. 2008) that initial mortality rates are likely to be very high if the virus were to be reintroduced in such naïve populations without immunity.

Obtaining samples from different cetacean species for morbillivirus serology through strandings is very difficult, as animals are often too decomposed for blood sample collection (Gulland 1999). Most samples in this study were obtained from animals that stranded alive and then died or were euthanized. Here we investigated morbillivirus titers in samples collected from these sources and found that three bottlenose dolphins from the east and Gulf of Mexico coasts of the United States were seropositive. This is in line with the findings from the capture-release studies. Perhaps an important finding was the very high titer in a stranded rough-toothed dolphin from the Gulf of Mexico, sampled in August 2004. Although an isolated case, it could indicate the circulation of the virus in these offshore species. However, it is only a single animal and is in contrast to the results from a group of animals that live stranded the same year and region and that were all seronegative. This illustrates the problem of making inferences about exposure among particular species in specific regions from single stranded animals and the need for continued long-term surveillance studies that will allow sample sizes to increase with time and opportunity.

\section{ACKNOWLEDGMENTS}

We thank the many researchers who participated in the live capture-release efforts in Beaufort, NC; Charleston, SC; Sarasota, FL; and St. Joseph Bay, FL. Sampling in Beaufort, NC and Charleston, SC was conducted by NMFS Southeast Fisheries Science Center under NMFS Scientific Research Permit Nos. 960 and 779-1681-00. Sampling in St. Joseph Bay, Florida

\footnotetext{
${ }^{2}$ It should be noted that no dolphins $>37 \mathrm{yr}$ of age have been sampled since 2001, in spite of the presence of residents in their $40 \mathrm{~s}$ and $50 \mathrm{~s}$ in the population.
} 
was conducted under NMFS Marine Mammal Health and Stranding Response Program Permit No. Permit No. 932-1489. Field sampling in Sarasota, Florida, was conducted under NMFS Scientific Research Permit Nos. 522-1569 and 522-1785, approved by the Mote Marine Laboratory Institutional Animal Care and Use Committee, and supported by NMFS, Dolphin Quest, and the Chicago Zoological Society. We also extend our thanks to the dedicated volunteers of the U.S. Southeast and Northeast Marine Mammal Stranding Networks.

\section{Literature Cited}

Aguilar, A., and J. A. Raga. 1993. The striped dolphin epizootic in the Mediterranean Sea. Ambio 22:524-528.

Barrett, T., I. K. Visser, L. Mamaev, L. Goatley, M. F. van Bressem and A. D. Osterhaus. 1993. Dolphin and porpoise morbilliviruses are genetically distinct from phocine distemper virus. Virology 193:1010-1012.

Barrett, T., M. Blixenkrone-Moller, G. Di Guardo, M. Domingo, P. Duignan, A. J. Hall, L. Mamaev and A. D. Osterhaus. 1995. Morbilliviruses in aquatic mammals: Report on round table discussion. Veterinary Microbiology 44:261-265.

Birkun, A., T. Kuiken, S. Krivokhizhin, D. M. Haines, A. D. M. E. Osterhaus, M. W. G. Van deBildt, C. R. Joiris and U. Siebert. 1999. Epizootic of morbilliviral disease in common dolphins (Delphinus delphis ponticus) from the Black Sea. Veterinary Record 144:85-92.

Bonilla, F. A., I. L. Bernstein, D. A. Khan, Z. K. Ballas, J. Chinen, M. M. Frank, L. J. Kobrynski, A. I. Levinson, B. Mazer, R. P. Nelson, Jr., J. S. Orange, J. M. Routes, W. T. Shearer and R. U. Sorensen. 2005. Practice parameter for the diagnosis and management of primary immunodeficiency. Annals of Allergy, Asthma and Immunology 94:S1-S63.

Cornwell, H., S. Anderson, P. Thompson, S. Mayer, H. Ross, P. Pomeroy and R. Munro. 1992. The serological response of the common seal (Phoca vitulina) and the grey seal (Halichoerus grypus) to phocine distemper virus as measured by a canine distemper virus neutralisation test. Science of the Total Environment 99:115-116.

Corthésy-Theulaz, I., B. Corthésy, D. Bachmann, D. Velin and J. P. Kraehenbuhl. 2003. Passive immunity in Helicobacter-challenged neonatal mice conferred by immunized dams lasts until weaning. Infection and Immunity 71:2226-2229.

Dietz, R., C. T. Ansen, P. Have, and M.-P. Heide-Jørgensen. 1989. Clue to seal epizootic? Nature 338:627.

Domingo, M., L. Ferrer, M. Pumarola, A. Marco, J. Plana, S. Kennedy, M. McAliskey and B. K. Rima. 1990. Morbillivirus in dolphins. Nature 348:21.

Duignan, P. J., J. T. Saliki, D. J. St. Aubin, J. A. House and J. R. Geraci. 1994. Neutralizing antibodies to phocine distemper virus in Atlantic walruses (Odobenus rosmarus rosmarus) from Arctic Canada. Journal of Wildlife Diseases 30:90-94.

Duignan, P. J., C. House, J. R. Geraci, G. Early, H. G. Copland, M. T. Walsh, G. D. Bossart, C. Cray, S. Sadove, D. St. Aubin and M. Moore. 1995a. Morbillivirus infection in two species of pilot whales Globicephala sp from the Western Atlantic. Marine Mammal Science 11:150-162.

Duignan, P., J. T. Saliki, D. J. St. Aubin, G. Early, S. Sadove, J. A. House, K. Kovacs and J. Geraci. 1995b. Epizootiology of morbillivirus infection in North American harbor seals (Phoca vitulina) and gray seals (Halichoerus grypus). Journal of Wildlife Diseases 31:491-501.

Duignan, P. J., C. House, D. K. Odell, R. S. Wells, L. J. Hansen, M. T. Walsh, D. J. St. Aubin, B. Rima and J. R. Geraci. 1996. Morbillivirus infection in bottlenose dolphins: Evidence for recurrent epizootics in the Western Atlantic and Gulf of Mexico. Marine Mammal Science 12:499-515.

Fernandez, A., F. Esperon, P. Herraez, A. E. De Los Monteros, C. Clavel, A. Bernabe, J. M. Sanchez-Vizcaino, P. Verborgh, R. Destephanis, F. Toledano and A. Bayon. 2008. Morbillivirus and pilot whale deaths, Mediterranean Sea. Emerging Infectious Diseases 14:792-794. 
Geraci, J. 1989. Clinical investigation of the 1987-1999 mass mortality of bottlenose dolphins along the US Central and south Atlantic coast. Final Report to National Marine Fisheries Service, U.S. Navy Office of Naval Research, and Marine Mammal Commission. 63 pp.

Gulland, F. M. 1999. Stranded seals: Important sentinels. Journal of the American Veterinary Medical Association 214:1191-1192.

Hall, A. J. 1995. Morbilliviruses in marine mammals. Trends in Microbiology 3:4-9.

Haydon, D. T., S. Cleaveland, L. H. Taylor and M. K. Laurenson. 2002. Identifying reservoirs of infection: A conceptual and practical challenge. Emerging Infectious Diseases 8:14681473.

Hohn, A. A., M. D. Scott, R. S. Wells, J. C. Sweeney and A. B. Irvine. 1989. Growth layers in teeth from known-age, free-ranging bottlenose dolphins. Marine Mammal Science 5:315-342.

Itoh, M., O. Okuno and H. Hotta. 2002. Comparative analysis of titers of antibody against measles virus in sera of vaccinated and naturally infected Japanese individuals of different age groups. Journal of Clinical Microbiology 40:1733-1738.

Kennedy, S. 1998. Morbillivirus infections in aquatic mammals. Journal of Comparative Pathology 119:201-225.

Kennedy, S., J. A. Smyth, P. F. Cush, S. J. McCullough, G. M. Allan and S. McQuaid. 1988. Viral distemper now found in porpoises. Nature 336:21.

Lipscomb, T. P., S. Kennedy, D. Moffett and B. K. Ford. 1994a. Morbilliviral disease in an Atlantic bottlenose dolphin (Tursiops truncatus) from the Gulf of Mexico. Journal of Wildlife Diseases 30:572-576.

Lipscomb, T. P., F. Y. Schulman, D. Moffett and S. Kennedy. 1994b. Morbilliviral disease in Atlantic bottlenose dolphins (Tursiops truncatus) from the 1987-1988 epizootic. Journal of Wildlife Diseases 30:567-571.

Lloyd-Smith, J. O., D. J. Greig, A. Hietala, G. S. Ghneim, L. Palmer, J. St Leger, B. T. Grenfell and F. M. D. Gulland. 2007. Cyclical changes in seroprevalence of leptospirosis in California sea lions: Endemic and epidemic disease in one host species? BMC Infectious Disease 7:125-136.

Markussen, N. H., and P. Have. 1992. Phocine distemper virus infection in Harp seals Phoca groenlandica. Marine Mammal Science 8:19-26.

Marschner, I. C. 1996. Fitting a multiplicative incidence model to age- and time-specific prevalence data. Biometrics 52:492-499.

McCullough, S., F. McNeilly, G. Allan, S. Kennedy, J. A. Smyth, S. L. Cosby, S. McQuaid and B. K. Rima. 1991. Isolation and characterisation of a porpoise morbillivirus. Archives of Virology 118:247-252.

Nielsen, O., R. E. Stewart, L. Measures, P. Duignan and C. House. 2000. A morbillivirus antibody survey of Atlantic walrus, narwhal and beluga in Canada. Journal of Wildlife Diseases 36:508-517.

OIE, the World Organisation for Animal Health. 2008. Manual of diagnostic tests and vaccines for terrestrial animals, 2008. OIE Biological Standards Commission, Paris, France. 1341 pp. Available at http://www.oie.int/eng/normes/mmanual/.

Osterhaus, A., and E. J. Vedder. 1988. Identification of virus causing recent seal deaths. Nature 335:20.

Pomeroy, P. P., J. A. Hammond, A. J. Hall, M. Lonergan, C. D. Duck, V. J. Smith, and H. Thompson. 2005. Morbillivirus neutralizing antibodies in Scottish grey seals: Assessing the effects of the 1988 and 2002 PDV epizootics. Marine Ecology Progress Series 287:241-250.

Raga, J.-A., A. Banyard, M. Domingo, M. Corteyn, M.-F. Van Bressem, M. A. Fernández, F.-J. Aznar, and T. Barrett. 2008. Dolphin morbillivirus epizootic resurgence, Mediterranean Sea. Emerging Infectious Diseases 14:471-473.

Rossiter, P. B., D. M. Jessett and W. P. Taylor. 1985. Microneutralization system for use with different strains of peste des petits ruminants and rinderpest virus. Tropical Animal Health and Production 17:75-81. 
Saliki, J. T., and T. W. Lehenbauer. 2001. Monoclonal antibody-based competitive enzymelinked immunosorbent assay for detection of morbillivirus antibody in marine mammal sera. Journal of Clinical Microbiology 39:1877-1881.

Saliki, J. T., E. J. Cooper and J. P. Gustavson. 2002. Emerging morbillivirus infections of marine mammals: Development of two diagnostic approaches. Annals of the New York Academy of Sciences 969:51-59.

Schwacke, L., A. J. Hall, R. S. Wells, G. Bossart, P. Fair, A. Hohn, P. Becker, J. Kucklick, G. Mitchum, P. Rosel, J. Whaley and T. Rowles. 2004. Health and risk assessment for bottlenose dolphin (Tursiops truncatus) populations along the southeast United States coast: Current status and future plans. Paper SC/56/E20 presented to the IWC Scientific Committee, July 2004.

Scott, M. D., R. S. Wells and A. B. Irvine. 1990. A long-term study of bottlenose dolphins on the west coast of Florida. Pages 235-244 in S. Leatherwood and R. R. Reeves, eds. The bottlenose dolphin. Academic Press, San Diego, CA.

Taubenberger, J. K., M. Tsai, A. E. Krafft, J. H. Lichy, A. H. Reid, F. Y. Schulman and T. P. Lipscomb. 1996. Two morbilliviruses implicated in bottlenose dolphin epizootics. Emerging Infectious Diseases 2:213-216.

Thompson, P. M., H. J. C. Cornwell, H. M. Ross and D. Miller. 1992. Serologic study of phocine distemper in a population of harbor seals in Scotland. Journal of Wildlife Diseases 28:21-27.

Thompson, P. M., H. Thompson and A. J. Hall. 2002. Prevalence of morbillivirus antibodies in Scottish harbour seals. Veterinary Record 151:609-610.

Van Bressem, M. F., I. K. G. Visser, M. W. G. Van De Bildt, J. S. Teppema, J. A. Raga and A. D. M. E. Osterhaus. 1991. Morbillivirus infection in Mediterranean striped dolphins (Stenella coeruleoalba). Veterinary Record 129:471-472.

Van Bressem, M. F., K. Van Waerebeek, M. Fleming and T. Barrett. 1998. Serological evidence of morbillivirus infection in small cetaceans from the Southeast Pacific. Veterinary Microbiology 59:89-98.

Van Bressem, M. F., K. Van Waerebeek, P. D. Jepson, J. A. Raga, P. J. Duignan, O. Nielsen, A. P. Di Beneditto, S. Siciliano, R. Ramos, W. Kant, V. Peddemors, R. Kinoshita, P. S. Ross, A. Lopez-Fernandez, K. Evans, E. Crespo and T. Barrett. 2001. An insight into the epidemiology of dolphin morbillivirus worldwide. Veterinary Microbiology 81:287-304.

Visser, I. K. G., V. P. Kumarev, C. Orvell, P. de Vries, H. W. J. Broeders, M. W. G. van de Bildt, J. Groen, J. S. Teppema, M. C. Burger, F. G. C. M. UytdeHaag and A. D. M. E. Osterhaus. 1990. Comparison of two morbilliviruses isolated from seals during outbreaks of distemper in North West Europe and Siberia. Archives of Virology 111:149-164.

Visser, I. K., M. F. Van Bressem, R. L. de Swart, M. W. van de Bildt, H. W. Vos, R. W. Van Der Heijden, J. T. Saliki, C. Orvell, P. Kitching, T. Kuiken and A. D. M. E. Osterhaus. 1993. Characterization of morbilliviruses isolated from dolphins and porpoises in Europe. Journal of General Virology 74:631-641.

Wells, R. S., and M. D. Scott. 1990. Estimating bottlenose dolphin population parameters from individual identification and capture-release techniques. International Whaling Commission (Special Issue 12):407-415.

Wells, R. S., and M. D. Scott. 1999. Bottlenose dolphin Tursiops truncatus (Montagu, 1821). Pages 137-182 in S. H. Ridgway and R. Harrison, eds. Handbook of marine mammals. Volume 6. The second book of dolphins and porpoises. Academic Press, London, U.K.

Wells, R. S., H. L. Rhinehart, L. J. Hansen, J. C. Sweeney, F. I. Townsend, R. Stone, D. Casper, M. D. Scott, A. A. Hohn and T. K. Rowles. 2004. Bottlenose dolphins as marine ecosystem sentinels: Developing a health monitoring system. EcoHealth 1:246254.

Wells, R. S., V. Tornero, A. Borrell, A. Aguilar, T. K. Rowles, H. L. Rhinehart, A. Hofmann, W. M. Jarman, A. A. Hohn and J. C. Sweeney. 2005. Integrating potential life-history and reproductive success data to examine relationships with organochlorine compounds 
for bottlenose dolphins (Tursiops truncatus) in Sarasota Bay, Florida. Science of the Total Environment 349:106-119.

Welsh, M. J., C. Lyons, A. Trudgett, B. K. Rima, S. J. McCullough and C. Orvell. 1992. Characteristics of a cetacean morbillivirus isolated from a porpoise (Phocoena phocoena). Archives of Virology 125:305-311.

Zolman, E. S. 2002. Residence patterns of bottlenose dolphins (Tursiops truncatus) in the Stono River estuary, Charleston County, South Carolina, U.S.A. Marine Mammal Science 18:879-892.

Received: 18 May 2009

Accepted: 10 February 2010 